\title{
CIVIC EDUCATION FOR LOWER SECONDARY STUDENTS
}

\author{
Pāvels Jurs \\ Alīda Samuseviča \\ Liepaja University, Latvia
}

\begin{abstract}
Nowadays the question of the necessity for the civic upbringing in the general curriculum in the system of education of Latvia has been raised. At the same time students' knowledge as well as skills and attitude of civic education have not been fully analyzed. Before carrying out the particular reforms in the content of education, we must assess the situation and find a balanced, purposeful and theoretically reasonable holistic systemic approach for promotion of the citizenship. Through using theoretical and empirical research methods, the process of researching is characterized and the data that reflects students' civic knowledge, skills, attitude and values has been analyzed. This publication contains systematized conclusions that outline the possibilities for pedagogical activities that promote civic competence for students in the general education institutions.
\end{abstract}

Keywords: attitude, content of basic education, civic education, civic competence, knowledge, lower secondary education, skills, students, values.

\section{Introduction}

In the course of lower secondary education in Latvia, civic education is not included. Its elements are included in the subjects: "Social studies" and "The history of Latvia" and in class lessons (upbringing lessons) as well. The lack of a unified understanding of the importance of civic education and its integration in education process in the state does not have a positive effect on the process of obtaining civic knowledge, skills and values. It must be noted that civic education has a significant role in promoting civic competence which insures the development of civic participation and implementation of civic upbringing thus the success in the forming of a civic society.

The question of a unified approach to the civic upbringingat schools appeared in the parliamentary level in 2013 and now the creation process of a unified approach for upbringing is in a process. Civic upbringingis planned to be only as a part of the subject of class lesson (upbringing lesson), which is insufficient - an integrated approach for obtaining civic education through interconnecting various subjects. A systematic and theoretically reasonable pedagogic approach for the promotion of the civic competence of youngsters must be created in addition to the currently planned program for civic and national upbringing.

Currently it is not easy to make any conclusions about the planned civic and national upbringing program since it is only being created, but undeniably the goals: "to promote the feeling of belonging to the state and its basic values; 
to promote the understanding of democracy and the possibilities for civic participation; to develop the sense of responsibility towards the society and the environment; to strengthen national self-esteem and patriotism" (Latvijas Republikas Saeima, 2014) are in the context with the current social needs of the state and at the same time they are ambitious. Meanwhile the planned practical introduction of this program remains unclear.

The goal of the publication is define preconditions to develop integrated civic education curriculum. The goal of the research (which is reflected in the publication) isto diagnose the civic skills, knowledge and general attitude of students of the $9^{\text {th }}$ grade by basing on the analysis of the content of thelower secondary education subjects: "Social studies", "The history of Latvia" and by researching civic competence and civic education theoretically in order to create and approbate an educational program that promotes civic participation "The formation and development of civic competence for the integrated learning of civic education in the lower secondary stage" thus fully insuring the integrated learning of civic education in the $9^{\text {th }}$ grade.

To achieve the given goal the authors of the publication are using: theoretical methods (the research, selection, systematization, structuring and targeted analysis of legislative document and empirical methods (methods of data gathering, processing and analysis).

\section{The analysis of the content of basic education subjects "Social sciences" and "The history of Latvia"}

To analyze the content of education, the civic knowledge, civic skills, civic values and civic attitude of the students of the $9^{\text {th }}$ grade as the basis was used the rules of the Cabinet of Ministers No. 468 concerning the standards of lower secondary education, the standards of the subjects of lower secondary education and theexamples of programs of lower secondary education are used. The rules dictate:

1. the state standards of the lower secondary education which defines the main goals and objectives, the obligatory content of education and the principles and the order of assessment;

2. the lower secondary education subjects standards regulating the main aims and objectives of the subject, the content, the requirements for subject learning and the forms and methods of learning assessment (Cabinet of Ministers No. 468, 2014).

According to the General Education Law Article No.15 of the general education subjects standards define general education program aims and objectives of general education compulsory content, the principles and procedures of student learning assessment (Vispārējās izglītības likums, 1999). Reviewing the content of all subjects, being acquired at lower secondary stage it is concluded that the subjects' "The history of Latvia" and "Social studies" content is partly based on civic education. The main goal of the subject "The 
history of Latvia" is to improve the understanding of the basic tendencies of the development of humanity which promotes the formation of one's identity and promotes the development of a responsible and tolerant citizen of the democratic society of Latvia (Latvijas vēstures mācību priekšmeta standarts, 2014). Meanwhile, the goal of the subject "Social studies" is to promote the understanding of social processes as well as the ability of students to make and fulfill decisions that the society depends upon in their personal, professional, and social lives in a democratic society (Sociālo zinību mācību priekšmeta standarts, 2014).

In order to determine the civic knowledge, civic skills, civic attitudes and values, students must inhere starting learning in form 9 (Table 1), the sample programs of the subjects "The history of Latvia" (Jaunozola, 2011) and "Social studies" (Falka, 2014) have been analyzed inthe publication. These programs determine the curriculum, the learning process and capacity. Examples of subject programs, developed by National Centre for Education of the Republic of Latvia, conform tolower secondaryeducation and have recommendatory character. Despite the fact that examples of subject programshave recommendatory character, all national level tests and examinations are based on the educational content of these programs, because the development of the program has been closely linked with the standard of lower secondaryeducation.

Table 1. Analysis of the lower secondary education content: civic knowledge, skills, attitudes and values of students starting form 9

\begin{tabular}{|c|c|c|}
\hline $\begin{array}{l}\text { Acquired civic knowledge } \\
\text { in the subjects "Social } \\
\text { studies" and "The History of } \\
\text { Latvia" }\end{array}$ & $\begin{array}{l}\text { Acquired civic skills in the } \\
\text { subjects "Social studies" } \\
\text { and "The History of Latvia" }\end{array}$ & $\begin{array}{l}\text { Acquired civic attitudes } \\
\text { and values in the subjects } \\
\text { "Social studies" and "The } \\
\text { History of Latvia" }\end{array}$ \\
\hline $\begin{array}{l}\text { 1. Know about their } \\
\text { opportunities to influence } \\
\text { the quality of the } \\
\text { environment. } \\
\text { 2. Know about the regions } \\
\text { of Latvia, neighboring } \\
\text { countries, the national } \\
\text { symbols of Latvia. } \\
\text { 3. Know about cultural and } \\
\text { historical traditions in } \\
\text { Latvia. } \\
\text { 4. Know about democratic } \\
\text { electoral system. } \\
\text { 5. Know about the } \\
\text { objectives of the state. } \\
\text { 6. Know about the rights } \\
\text { and obligations. } \\
\text { 7. Know about the social } \\
\text { structure of the society. }\end{array}$ & $\begin{array}{l}\text { 1. Skill to assume the duties } \\
\text { and use their rights (e.g., } \\
\text { opportunities provided by } \\
\text { School self-management } \\
\text { or co-management). } \\
\text { 2. Co-operation skills. } \\
\text { 3. Skill to analyze different } \\
\text { points of view, the } \\
\text { assessing facts and } \\
\text { expressing opinion based } \\
\text { on argumentation. } \\
\text { 4. The skill to recognize the } \\
\text { usefulness of the } \\
\text { knowledge about the } \\
\text { history toevaluate the } \\
\text { present situation. } \\
\text { 5. The readiness to make } \\
\text { decisions based on } \\
\text { economic, legal and }\end{array}$ & $\begin{array}{l}\text { 1. The solidarity and } \\
\text { helpfulness in the field of } \\
\text { human relationships. } \\
\text { 2. The values of family, } \\
\text { home, motherland in } \\
\text { personal and other } \\
\text { people's lives. } \\
\text { 3. The readiness to } \\
\text { recognize the rights to } \\
\text { have different beliefs. } \\
\text { 4. Tolerance and liberality. } \\
\text { 5. The readiness to build } \\
\text { positive, respectful } \\
\text { mutual relations with } \\
\text { other people. } \\
\text { 6. The respectful attitude } \\
\text { towardthe history of } \\
\text { family, city and state. }\end{array}$ \\
\hline
\end{tabular}




\begin{tabular}{|c|c|c|c|}
\hline \multicolumn{2}{|l|}{$\begin{array}{l}\text { 8. Know the national } \\
\text { celebrations and } \\
\text { commemorations of } \\
\text { Latvia. } \\
\text { 9. Know and understands } \\
\text { the concept of patriotism. }\end{array}$} & & ethical considerations \\
\hline
\end{tabular}

After summarizing the analysis of basic education content of the subjects "Social Studies" and "The history of Latvia" for students after graduating form 8 and entering form 9, it can be concluded that:

1) students' skills have not been developed in the field of civic participation in various socially significant activities;

2) the skills to participate in decision-making processes have not been developed, as well as seeing the role of individual in the context of civic participation;

3) leadership skills have not been developed. These skills are essential component in the process of personal development and promotes the socialization and expression of civic participation;

4) despite the fact that students should be open to diversity and be tolerant, the analysis of basic education content shows that the students' knowledge on tolerance issues is not being formed;

5) the acquisition of school subjects is based on theoretical issues. However, there is a lack of practical component which prepares students for the existing realities of life in a rapidly changing globalized world.

\section{The determination of students' civic knowledge, skills, attitudes and values, using the developed diagnostic tests and questionnaires}

The target populations of conducted diagnostic study were students of Liepaja Secondary School No. „X”. form 9, the total of 83 respondents (39 girls and 44 boys).

Being aware of each student's individuality; challenges of obtaining curriculum; the existing pedagogical reality and different learning levels of students, it is necessary in to determine the students' civic knowledge practically. Therefore, based on the analysis of the content of basic education subjects "Social Studies" and "The history of Latvia", diagnostic test was developed. Within this test students had to show their knowledge on national symbols, cultural and historical traditions, festivals and commemorations, rights and obligations, the governmental functions and administration. It should be noted that students did not have special preparation for this test. There was the description of personal attitude towards the Republic of Latvia included in the second part of the diagnostic test, where students had to distinguish 
himself/herself as an integral part of the country. The run time of the test was 50 minutes. The test was accomplished within two lessons.

The authors of the publication developed a questionnaire in order to identify students' civic skills, attitudes and values. There were 27 questions included in the first part of the survey, assessing students' active citizenship, tolerance, a sense of belonging to the school, city, country, the value of life and habits. There were 37 statements reflecting students' behavior in the context of civic engagement, awareness and attitudes towards their school, city, country and the European Union. The run time of the survey was 40 minutes.

The diagnostic test and the survey are based on the analyzed studies about framework of civic competence, civic education content (Jurs, 2014) as well as realizing the regulatory framework of the curriculum of the education of the Republic of Latvia - the Cabinet of Ministers No.468 standard of lower secondary education, subject standards and lower secondary education curriculum.

\section{Analysis of students' civic knowledge}

Summarizing the overall results of diagnostic tests (summarized in Figure No.1), it should be noted that the average level of students' graduating form 8 achievement in the field of civic knowledge is only $64.56 \%$. The results shown in the context of educational content of subjects "Social Studies" and "The History of Latvia" only reinforces the necessity for civic education in integrated learning using multiple teaching methods and providing individual approach.

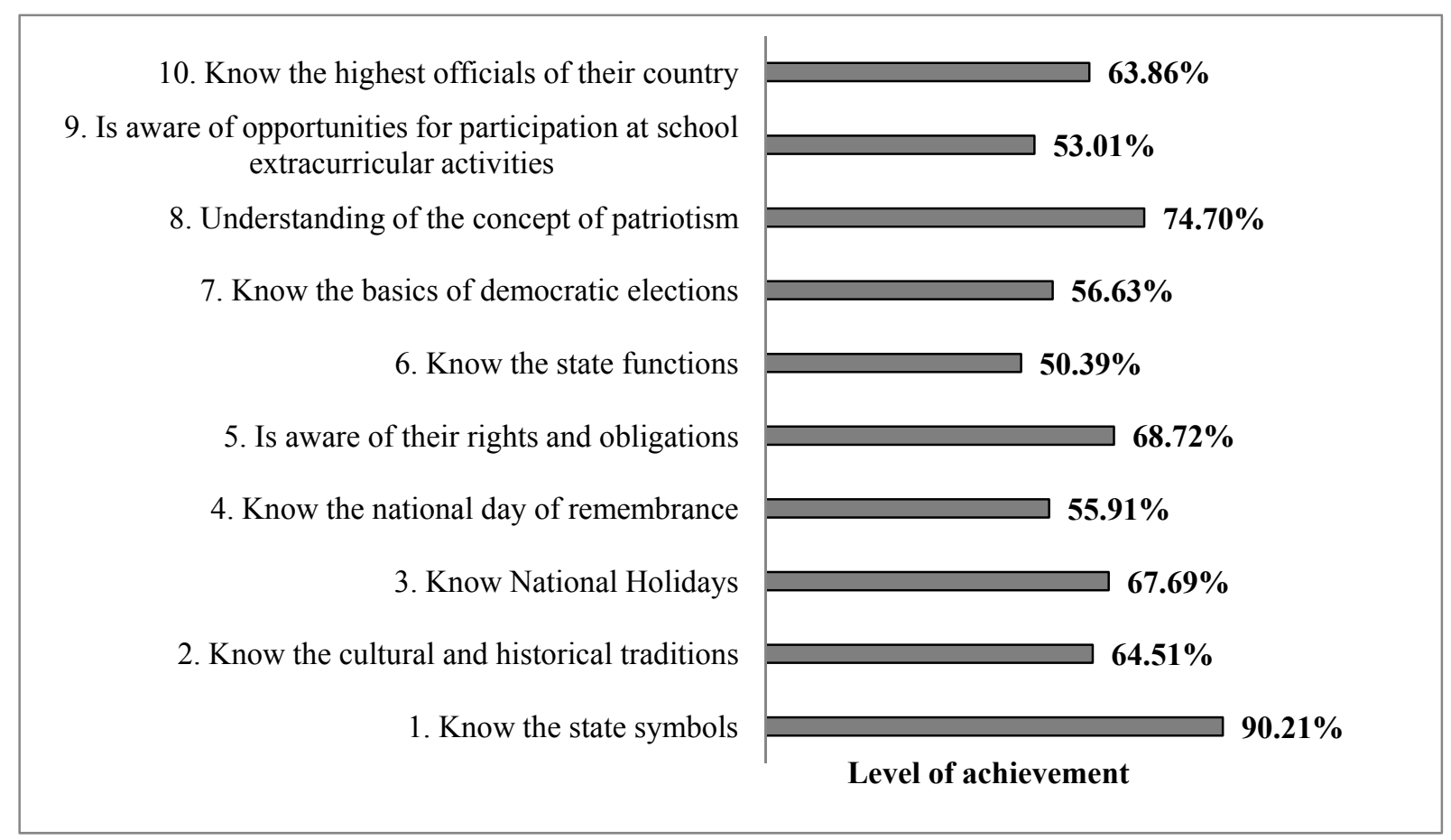

Figure 1. The diagnosis of civic knowledge of the $9^{\text {th }}$ grade students $(n=83)$ 
From the analysis of assertions highlighted in students' descriptions, it can be concluded the majority of students $(74.70 \%)$ link their future with Latvia and Latvia is characterized as a capable state, as a beautiful land and their homeland which needs to be protected, while $25.30 \%$ of students do not see their place in Latvia, as well as their contribution to Latvia. They have emphasized that Latvia is not citizen-friendly state and the continuing unemployment has been mentioned as one of the negative aspects in the country. It should be noted that all of the students have mentioned a variety of existing socio-economic problems in the country and they are concerned about potential military threat to Latvia.

Students face difficulties defining their contribution to the further development of Latvia, so good learning achievements have been mentioned as positive input. This fact reflects to the inability of students to assess their potential contribution to, for example, participation in various social campaigns, significant national events, etc.

Analyzing the results of diagnostic test, the following can be concluded:

1) students graduating form 8, have only partially obtained civic knowledge. The acquisition of civic knowledge in accordance with the rules of the Cabinet of Ministers No. 468 of the national standard of basic education, subject standards and basic curriculum is designed for subjects "Social Studies" and "The history of Latvia";

2) one-third of the students of $9^{\text {th }}$ grade cannot name any of cultural and historical traditions of Latvia, which is an unsatisfactory indicator. Cultural and historical traditions are reflected to national values and history;

3) the students' understanding of the rights and obligations is mainly related to their current necessity: the right to education, health, life and freedom of expression have mainly mentioned by the students. However, obligations: to learn, to help parents, to comply with the law, to respect others have not been mentioned;

4) one-third of the students of $9^{\text {th }}$ grade do not know the functions of the state, thus their understanding about the responsibilities of the state in the relation to the population is unclear. They do not distinguish the difference of the roles and responsibilities of legislature, executive and public sector;

5) a quarter of the $9^{\text {th }}$ grade students cannot explain the concept of patriotism, which confirms the lack of understanding of the meaning and essence of patriotism;

6) in spite of the fact that students' participation at school life is provided by students' co-management, offering the opportunity to be engaged in shaping their school life, half of the students of $9^{\text {th }}$ grade do not know about this possibility. 


\section{The analysis students' civic skills, attitudes and values}

Summarizing the gathered data $(n=83)$, a number of significant tendencies in the educational process have been observed:

1. Civic passivity and the lack of understanding of the concept of patriotism

The majority of students $(53.01 \%)$ consider themselves to be civically inactive and a considerable part of students (43.37\%) do not recognize themselves as patriots of the country. Thusthe negative trend in the youngsters'self-assessment and attitude has been marked. Unfortunately, low self-esteem in students' civic activities, is suitable with the low civic participation of students (Figure No.2). Individual civic position, which is formed by civic membership, is an essential prerequisite for the promotion of civic society.

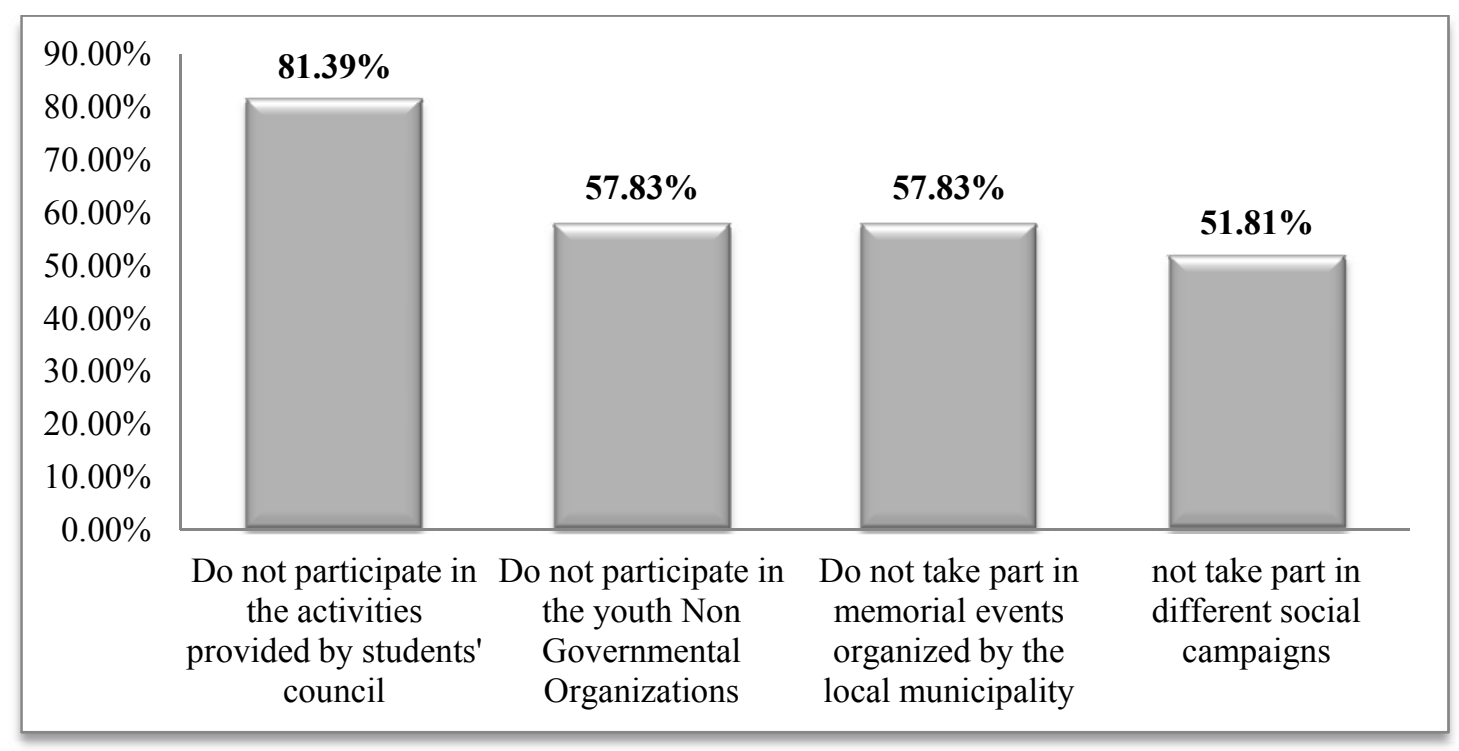

Figure 2. The expressions of civic participation of the students of $9^{\text {th }} \operatorname{grade}(n=83)$

Civic passivity, the decrease in patriotic feelings can lead to the indifference towards the state. Indifferent attitude to the social processes and the country only reduces the sense of belonging to the country of individual. Thusthe development of the country has been affected as well.

Self-assessment of patriotism, showed probably incomprehension of respondents in the field of the concept of the nature of patriotism. The assessment of their patriotism, expresses personal attitude $-43.37 \%$ of the respondents do not consider themselves as patriots.

Thus educational content and professional pedagogical work gain special attention to raise awareness of civic participation and patriotism of students. This consequently promotes students' understanding and highlights the necessity for civic participation and the importance of patriotism. 


\section{Intolerance - lack of tolerance}

Only $53.41 \%$ of respondents characterized themselves as tolerant toward the different view, religion and race of other people.

The issues of tolerance in the multicultural society are an essential prerequisite for intercultural cooperation and peacekeeping. Europeans are already becoming increasingly diversified. The European Commission's 2012 survey conducted by the European Union member states shows that two of three Europeans have friends with different religion or belief, but three of five Europeans have friends with different ethnic origin. At the same time, ethnic origin, despite the reduction trend, is still most widely used example of discrimination in the European Union in 2012 - 56\%, while in $2009-61 \%$ (European Commission, 2012).

Tolerance is an important aspect of the development process of personality, and one of the factors that forms an individual's civiccompetence. The promoting of tolerance in the multicultural society of the $21^{\text {st }}$ century is essential for both: the development of intercultural dialogue and the reduction of geopolitical problems. Today, a new generation must be prepared to accept differences, to have a respect for diversity, to be tolerant.

3. The low grade of dignity and sense of belonging toward the European Union

Students, starting learning in form 9, have little knowledge and awareness on the issues of European Union; they are not able to see the European Union's contribution to the future prospects of Latvia. This leads to a logical attitude of students - only $53.01 \%$ of respondents feel the dignity toward the European Union, but only $38.55 \%$ of respondents have sense of belonging to European Union. The situation can be explained by the students' lack of experience and knowledge. They have not been in the direct contact with the European Union in the most direct way, so the European Union is an abstract concept for them.

With a regard to the potential students' knowledge, the curriculum at lower secondary education stage involves the acquisition of topics on European Union and the participation of Latvia in EU. These issues are involved in form 6 - the subject: "The history of Latvia" and the $2^{\text {nd }}$ semester of form 9 - the subject: "Social Studies" and partly have been involved in subjects "The history of the world" and "The History of Latvia". Here the following problem has been highlighted: students starting learning the issues of the European Union in form 6 , and after a gap, continuing these studies in form 9 , have forgotten the gained knowledgein this field and even organized campaigns have not raised their awareness.

\section{The lack of communication between students and parents}

The formation and development ofstudents' personality is not possible without a family support: students'awareness and understanding of the importance of civic engagement has been developed in family. Here the forming factors are the observing of the parents' attitude, which is eventually in the 
process of formingthe child's own attitude (World Bank, 2007). At the same time, recognizing the existing socio-economic situation, e.g. busy parents, it should be noted that, despite the leading role of the family in the formation process of civic competences, civic participation and promoting the valuesof the younger generation, the objective reality shows that parents and children are often in the lack of mutual communication, to discuss the questions about individual responsibility, civic engagement or different current events in Latvia and Europe (Figure No.3).

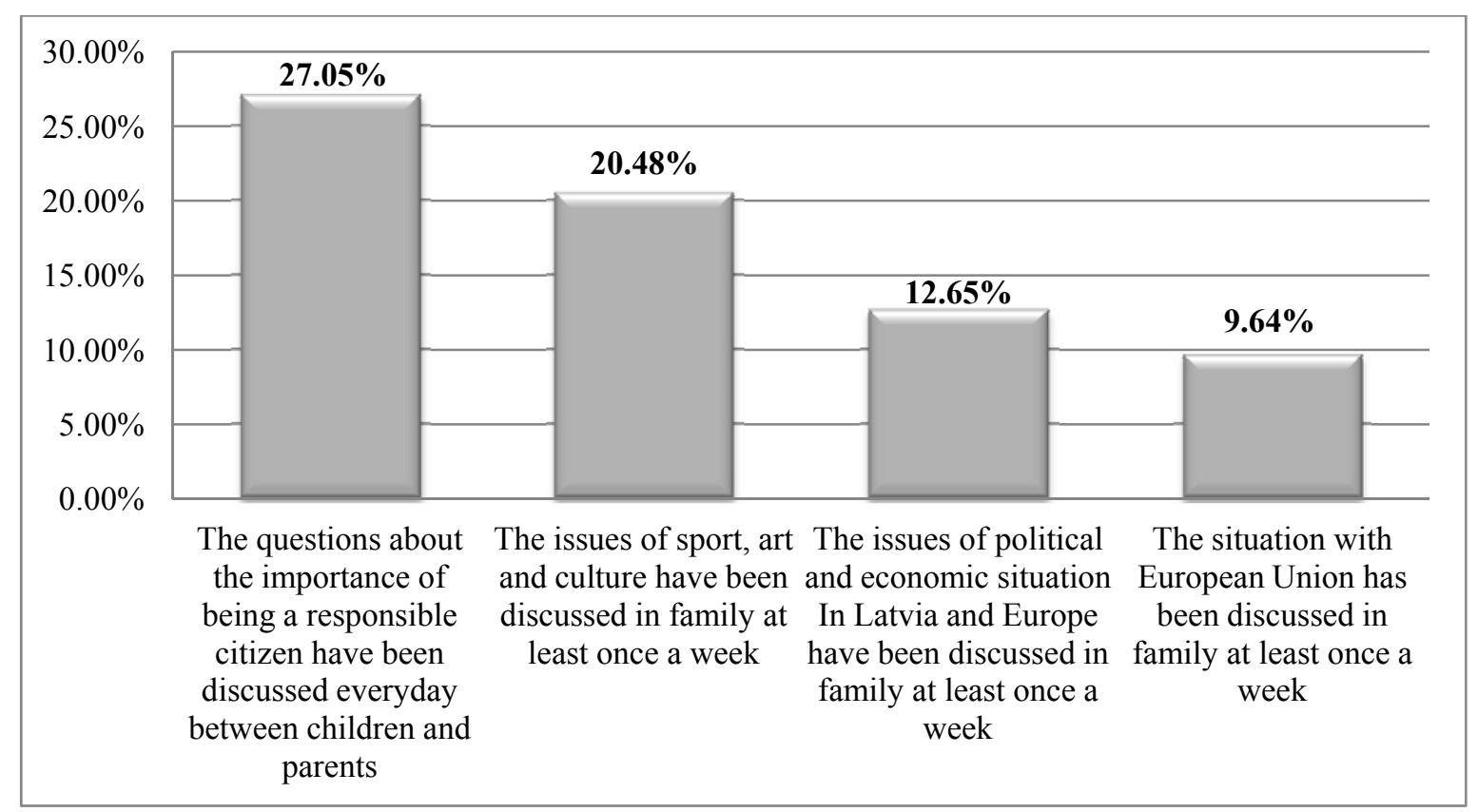

Figure 3. The communication of students and parents about civic responsibility and the variety of topical issues in Latvia and Europe

Analyzing the survey results, the authors of publication can conclude that:

1) students' self-assessment showed, that the intended knowledge of civic skills, attitudes and values according to the curriculum (subjects "Social Studies" and "The history of Latvia") graduating form 8, have been only partly acquired. This fact highlights the necessity for the promotion of civic competence at schools, revising curricula and focusing on the preparing students for life in an objective and challenging reality;

2) the students' civic engagement can be described as passive. The reason of this situation can be the lack of positive experience;

3) the students involved in the research cannot be described as tolerant individuals of the society;

4) the lack of children's and parents' mutual communication has been observed on the background of the existing social problems. 


\section{Conclusions}

In the process of the development of the integrated civic education curriculum "the creation and the development of civic competences for the integrated learning of civic education in lower secondary education" the following should be taken into account:

1) the holistic systematic approach to the process of formation of civic knowledge, civic skills, attitudes, values in the educational process;

2) pedagogical and educational opportunities of lower secondary curriculum subjects "Social Studies" and "The history of Latvia";

3) previously described and analyzed students' civic knowledge, skills, attitudes and values, and the improvement for the resources for their development throughvaried methodically didactic approach;

4) individual differences of students in the parameters of civic knowledge, skills, attitudes, considering each student's potential for growth;

5) educational and social characteristics of students, providing individual approach and the use of varied teaching forms and methods in the learning process and beyond it.

This work was partly funded by European Social Fund, project "Doktora studiju attīstība Liepājas Universitātē”, grant No.2009/0127/1DP/1.1.2.1.2./ 09/IPIA/VIAA/018.

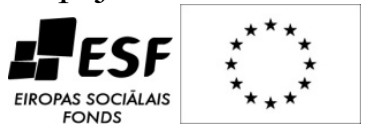

\section{References}

European Commission.(2012). Special Eurobarometer 393 - Discrimination in the EU in 2012.Brussels, 118, 120 p. Downloaded fromhttp://ec.europa.eu/public_opinion/ archives/ebs/ebs_393_en.pdf

Falka, S. (2014). Pamatizglītības mācību priekšmeta „Sociālās zin̄̄bas” programmas paraugs.Rīga: Valsts izglītības satura centrs. $8-12$ lpp. Downloaded fromhttp://visc.gov.lv/vispizglitiba/saturs/programmas.shtml

Jaunozola, V. (2011). Pamatizglìtības mācību priekšmeta „Latvijas vēsture” programmas paraugs.Rīga: Valsts izglìtības satura centrs. 9, 10, 14, 27, 28, 32, 33 lpp. Downloaded fromhttp://visc.gov.lv/vispizglitiba/saturs/programmas.shtml

Jurs, P. (2014.) Forming components of civic competence. (pp. 265-277) In:Journal of Teaching and Education, CD-ROM. ISSN: 2165-6266 :: 03(03), 266-271 p.

Latvijas Republikas Saeima. (2014). Likumprojekta „, Grozījumi Izglītības likumā” anotācija. Rīga. Downloaded from http://titania.saeima.lv/LIVS11/saeimalivs11.nsf/0/ 7BC42E71AD1BD524C2257D4900223FFA?OpenDocument

Latvijas vēstures mācību priekšmeta standarts 6.-9.klasei. (2014). 17.pielikums Ministru kabineta noteikumi Nr. 468 par valsts pamatizglìtības standartu, pamatizglīî̄bas mācību priekšmetu standartiem un pamatizglîtības programmu paraugiem. Rīga. Downloaded fromhttp://likumi.lv/doc.php?id=268342\#piel17\&pd=1 


\section{SOCIETY. INTEGRATION. EDUCATION. Volume II}

Ministru kabineta noteikumi Nr. 468 par valsts pamatizglìtības standartu, pamatizglītības mācību priekšmetu standartiem un pamatizglìtības programmu paraugiem. (2014). Rīga. Downloaded fromhttp://likumi.lv/doc.php?id=268342

Sociālo zinību. mācību priekšmeta standarts 1.-9.klasei. (2014). 18.pielikums Ministru kabineta noteikumi Nr. 468 par valsts pamatizglìtības standartu, pamatizglītības mācību priekšmetu standartiem un pamatizglītības programmu paraugiem. Rīga. Downloaded fromhttp://likumi.lv/doc.php?id=268342\#piel18\&pd=1

Vispārējās izglītības likums. (1999). Latvijas Republikas Saeima, Rīga. Downloaded fromhttp://likumi.lv/doc.php?id=20243

World Bank. (2007). World Development Report 2007: Development and the next generation. Washington DC, $166 \mathrm{p}$. 